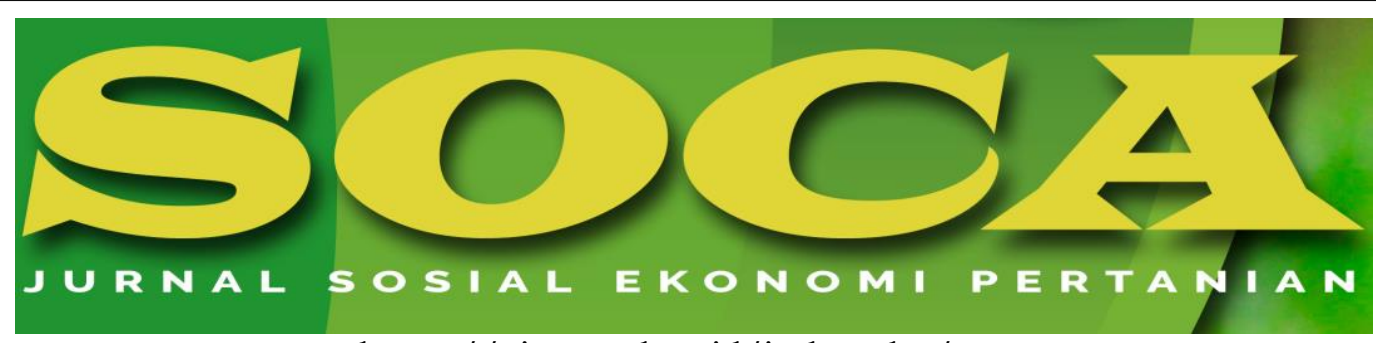

https://ojs.unud.ac.id/index.php/soca

\title{
Women and Onion Farming in Lakor Island, Southwest Maluku Regency
}

\author{
Junianita Fridianova Sopamena \\ Agricultural Socio-Economic Department, Faculty of Agriculture, Pattimura University, Ambon, \\ Maluku \\ Email: junianitasopamena@gmail.com \\ Mobile: 08114705552
}

Submitted: 16 January 2020; Revised: 27 January 2020; Accepted: 22 February 2020

\begin{tabular}{l} 
Keywords: \\
acceptance \\
contribution; \\
women; Lakor \\
island; onion \\
farming \\
\hline
\end{tabular}

\begin{abstract}
Abstrak
Up to this day, research on women-related topics has not completely revealed the independent contribution of women towards household income. This research's aim was to analyze the existence of women' contributions to their household income through onion farming on Lakor Island. The research data was chosen deliberately of 30 women who did onion farming in Werwawan Village, Lakor Island. The data collection was done by intense interview techniques and data confirmation to the related parties such as instructors and sellers. The data obtained through direct involvement of researchers using a list of questions, as well as direct observation to the women's activities in onion farming as a reflection of a qualitative approach. The results showed that most of the women engaged in onions farming independently, by utilizing home yards until open a land with an area of 1-2 hectares. The onion farming activities, contributed around Rp. 1,500,000 - 2,500,000 per planting season without assistance from men (husband). The contribution of women to household income reaches 60-80 percent. Therefore, women play an important role in improving the household economy through their contribution to household income.
\end{abstract}

How to Cite (APA 6th Style):

Sopamena, J. F. (2020). Women and Onion Farming in Lakor Island, Southwest Maluku Regency. SOCA: Jurnal Sosial Ekonomi Pertanian, 14(2), 265-274. https://doi.org/https://doi.org/10.24843/SOCA.2020.v14.i02.p07 


\section{INTRODUCTION}

Since then, the people of Lakor Island had known the work allocation between men and women. In general, the community admitted that all heavy work (which was defined by the community as clearing the forest) must be done by men. Whatever the condition of the family, including when the position of a woman as a single parent, so her brother played an important role in clearing forests that will be used as new farms. Clearing a forest is identical to opening a new farm, because in the agrarian structure of the Lakor people, there were only two terms associated with gardens; they are the Old Farm and the New Farm.

The process or phasing out which done by each family in principle was the same. The difference occurred if the farming area was still sufficiently available. Further studies of the activities in different areas (Big Island such as Babar and Wetar Island), need to be done by other researchers so it makes clear whether the structure of the Lakor type agrarian society is determined by the accessibility of the forest area (in the meaning of opening a new farm), or the activities in the island typology (big or small) stay the same.

During this time, research on women has not yet reached the analysis of their independent contribution to household income. Women were always attached to men, so that the results of their efforts were still merged with men (husbands). In fact, the context of the Lakor women especially in onion farming showed a maximum involvement of women without the help of men (husbands).

Lakor Island is a small island with an area of $303.02 \mathrm{~km} 2$ in Southwest Maluku Regency. Lakor Island consists of 5 (five) villages; they are Letoda, Ketty, Sera, Yamluli, and Lolotwara. The position of Lakor Island caused all activities to enter out of the Island is by sea, there is a Ferry Boats which once a week come to Lakor Island, Perintis Boats that visit the Lakor Harbor (Werwawan) every two weeks, as well as the routine community activities using speed boats or outboard motors with wooden frames who routinely catered Lakor to Moa or vice versa.

The results showed that small island people depends their lives from land and sea activities to meet the needs of their households. Women were also involved in efforts to meet their needs, through various household activities (Sopamena J. F., 2019a); (Sopamena \& Pattiselanno, 2018); (Sopamena J. F., 2019b); (Sopamena J. F., 2019c); and (Sahusilawane, 2019). Therefore, like small island people in Maluku, Lakor Island people also have two sides of exploited natural resources; land and sea. The land and sea resource exploitation culture has been passed down for generations as the main source of household income. (Central Bureau of Statistics Indonesia, 2017) (Central Bureau of Statistics Indonesia, 2018) showed that the total population of men and women on Lakor Island is almost balanced, with a sex ratio of 100.88. The equal number of women and men; opened opportunities for women to participate in supporting the fulfillment of household needs.

The research results (Sopamena J. F., 2019a); (Sopamena \& Pattiselanno, 2018); (Sopamena J. F., 2019b); (Sopamena J. F., 2019c); and (Sahusilawane, 2019) showed that women's contribution to meet household needs was very diverse. However, in terms of household income, women were able to contribute between 40 - 60 percent of total household income. This means, the role of women cannot be ignored in household activities. The research results also illustrated the relations of women and men on the Small Island, through the work alloction between men and women. 
This research wanted to reveal the presence of women in the activities to meet household needs, through onion farming which was done independently without the involvement of men (husband). In contrast to the previous researches that put women as supporters in contributing household income, this research revealed the position of women on Lakor Island who were fully involved in onion farming as one of the leading commodities in Southwest Maluku Regency. So far, there has been no research that discussed women in onion farming on Lakor Island. Thus, through this research the current position of women is illustrated and their independent contribution to household income. Therefore, this research aimed to analyze the presence of women in onion farming and its contribution to household income.

\section{RESEARCH METHODS}

The research was conducted in the Werwawan Village, Lakor Island. The Werwawan village was chosen intentionally, because it became one of the onion production centers in the Southwest Maluku Regency, which is well known as bun (konde) onion. The research was conducted for two months, September to October 2019. The sample was determined intentionally (purposive), that is, women farmers who do farming onions and joined in farmer groups. Therefore, there were 30 women farmers who were members of two onion farmer groups in Werwawan Village, Pulau Lakor. In addition, was selected the principles informant, agricultural Instructor (BPP Lakor Island Officers), Village Collector Sellers and Village Chairman to explore respondents' answers.

The primary data were collected by questionnaires given to respondents (Babbie, 2004) and in-depth interviews with principles informants (Debus \& Novelli, 1996). The data was also obtained by participatory observation (Norman \& Yvona, 1994) and (Babbie, 2004) where researchers must be directly involved in people's daily lives by listening to and differentiating what the community, as subjects of research, had said and did. Data analysis used a simple tabulation to describe the conditions and characteristics of the research location. The processed data is displayed in tables and diagrams to simplify the explanation of the research location conditions.

\section{RESULTS AND DISCUSSION}

\section{Allocation of Women's Solidarity in Farming}

Women and men have their respective positions and roles in the household. The differences in position and roles between the two are often also exchanged. The process of exchanging positions and roles depends on the situation and conditions encountered. (Sopamena J. F., 2018) explained that the allocation of solidarity is related to the role function of family members in household income and spending.

The women farmer households who work for onion farming showed that the roles and positions of women were more dominant than men. This fact is illustrated from the activities of women who are more seen and prominent compared to men. In general, there was no visible dominance of men in household activities. That means, the equality between men and women is more evident, compared to women's pressure because of the men position whose were considered higher.

When entering the onion farm, some women were seen doing the activity of cleaning the farm, while some were preparing a bucket to lift water to be used for watering the onion plants. Women considered that, what was done was an obligation. 
All women who were asked about this, explained that, the activities which done were women's obligations in the household.

The implementation of work that was interchangeable between women and men, showed the presence of mutual support in meeting household needs. In fact, replacing each other's role practice also showed the solidarity allocation between women and men, not only in activities related to household income contributions, but also the continuity of other household activities. This fundamental reality has changed a lot compared to the community point of view ten years ago. For example, research (Brumer, 2008) illustrated that, women in agriculture were under the domination of men. Even men and women were assumed to be heads and subordinates. The status of women as subordinates required them to do whatever is said by men as their heads. In fact, women on Lakor Island can move independently to run onion farming and be able to contribute to their household income. This means that there were no heads and subordinate positions for households in Lakor Island.

\section{The Integration Allocation and Expression in Farming}

The integration allocation and expression according to (Sopamena J. F., 2018) showed the presence of techniques or ways of socialization, as well as the preservation of values and behavior as the norm for each family member. The process of inheriting values from parents to children also happened in the onion farming process. One of the inheriting value processes is illustrated in the making of "lutur" (the land business area boundary) using stones that neatly arranged like fences. Lutur, if seen, was had dual functions, apart from being a land business area boundary, as well as a barrier to the livestock that were left free to enter. Livestock that were generally interfere the onion farming such as, goats, buffalo, and horses.

Referred to the results of the interview, actually the onion farming was the men responsibility. In addition to cultivating coconut as farming trees which will later be processed into copra as the main source of household income. But there were also those who processed coconut into coconut oil as a source of household food. The work of processing copra was dominated by men, while processing coconut oil was part of women' job. Generally, coconut was processed into copra and sold it to collectors. Coconut oil was made particularly for self-use as cooking oil.

The further explanation of the informants reinforced that there was no longer limitation of work between men and women. Especially the work area of women was no longer limited to work in the yard itself. However, it can also help in the practice of onion farming in a larger land. Women's activities and onion farming had just only been developing in recent years. Recent developments and the urgency of household needs have led men to develop businesses in other productive fields, such as animal husbandry and fisheries in addition to being workman. The activities of men in running onion farming were eventually taken over by women.

The values of onion commodity application that have been going for generations are passed on to children through a socialization process when children help their mothers on the land. The coconut as a prime commodity in plantation has always been the main source of income to support household income. In addition, onion which are now one of the leading commodities, were important for the structure of household income. Therefore, the process of onion farming then becomes a value passed down to the next generation, as well as showing the existence of the integration allocation and expression in the households on Lakor Island. 


\section{Political Allocation of Women in the Animal Husbandry and Fisheries Sector}

In the beginning, fisheries sector activities were complement strategies to meet the needs of household livelihood. Unlike onions and coconuts as the main source of income due to the continuity of production, the fisheries sector was much influenced by the weather. Generally, people go to the sea to meet family food needs. Fishing activities were done by catching fish using a net. The people also caught fish using spears when the water receded. All of that depends on the season that happened in this research location.

In general, it can be illustrated that, all processes of the activities of fisheries business sector were generally done by men. However, recent developments also showed that, women also supported men (husbands) in running a business on the coast. Even then, at certain times when men were out of the village, women took over the job by fishing using nets on the coast. All of that was part of the household livelihood strategy that was applied together, with joint decisions, and mutual support between the two parties. Therefore, no matter how busy women were, they still took time for fishing to meet household food needs. This was in accordance with the conception of Political Allocation, which was related to the sharing authority that became necessary at a certain level, as a responsibility of family members (Sopamena J. F., 2018).

On the animal husbandry sector, specifically, women were involved to help animal husbandry business (goats and buffaloes) after returning from grazing in the afternoon. In addition, if possible, the women also prepared food taken from the leftovers from the house. In addition, women prepared fodder in other forms, such as the skin of tubers and corn. The corn shell which quality was not so good used as animal feed. The works that were finished in the household; In accordance with the conclusions of the research (Sukesi, 2009) that, in a household environment, productive work can be done by both women and men, so that the limits of household job were not only related to reproductive work.

\section{The Sustainability Allocation in Farming}

The farming job was basically a public sector job. Structurally and culturally on the Lakor Island community, farming job was a male duty, as a form of responsibility for adult men who have decided to married. However, in the current development there was an opportunity for a point of view shifting so that the process of job allocation between men and women in society were changed. The point is such an allocation was actually to strengthen the continuity ongoing process of meeting the needs.

The outdoor job activities that carried out by men and women can be divided into four major parts; they are opening a farm, planting, cleaning the farm, and harvesting. Clearly, the job allocation between men and women in carrying out outdoor job activities (public) can be seen in Table 1 .

Table 1. The Job Allocation between Men and Women based on Farming Activites

\begin{tabular}{clcc}
\hline No & Outdoor Job Activities & \multicolumn{2}{c}{ Job Allocation (V = done) } \\
\cline { 3 - 4 } & & Men & Women \\
\hline 1 & Opening a Farm & $\mathrm{V}$ & $\mathrm{V}$ \\
2 & Planting & $\mathrm{V}$ \\
3 & Claning the Farm & $\mathrm{V}$ \\
4 & Harvesting & $\mathrm{V}$ \\
\hline Source & : Research Result Data (processed, 2019)
\end{tabular}


Based on Table 1, so the job allocation between men and women was also related to several outdoor activites besides farming; they were:

1. Sell the harvest

2. Buying household needs

3. Looking for information on farming activities

Futhermore based on the job allocation activities above, it can be mapped the job allocation between men and women as illustrated in Table 2 below.

Table 2. The Outdoor Job Allocation between Men and Women based on The Job besides Farming/in Village

\begin{tabular}{clccc}
\hline No & The Outdoor Job besides & Job Allocation (V = done) \\
\cline { 3 - 4 } & Farming/in Village & Men & Women \\
\hline 1 & Selling Harvest & $\mathrm{V}$ & $\mathrm{V}$ \\
2 & $\begin{array}{l}\text { Buying Household Needs } \\
3\end{array}$ & $\begin{array}{l}\text { Looking for information on farming } \\
\text { activities (farming, animal } \\
\text { husbandry, and seafood) }\end{array}$ & $\mathrm{V}$ & $\mathrm{V}$ \\
\end{tabular}

Source : Research Result Data (processed, 2019)

The job allocation of men and women in various activities in the domestic and public sectors, then there were three major parts of household job including the job inside the house, the job in the farm / village, and the outdoor job. This job allocation actually underlies the construction of gender in society. The activities of women and men in the concept of gender then spread in these three job activities. The gender constructions that were built in the community more showed the increasing role of women joined the activities in the farm and outdoor activities. The different conditions occurred in Afghanistan. Research (Srinivas, Malika, Aden, Barbara, Markos, \& Javed, 2013) found that women's involvement was less than men. This was possible because of a culture that strengthened by religion, prohibiting women to meet or face to face to men who were not their husbands. Women's activities were also very limited. More was allocated to just doing work at home.

\section{The Women in Public Activities}

The public activities undertaken by women have actually been reflected in household livelihood strategy activities. But the thing that emphasized in this public activity was activities outside the home/outdoor that were not related to meeting the needs of the household. Some of the public activities that have been carried out by women in recent years include:

1. Participating in the Farmer Group meetings and get involved in the group making decision, such as preparing Farmer Group Plans and in the decision making process to start the time for planting onions,

2. Following the $P K K$ (married women community in a village) meetings and activities, in accordance with the direction of the activities determined by the Village Head,

3. Attending routine worship in groups and every week worship in the Church. In routine group worship, the participation of women is quite dominant, even sometimes women lead and assisted in the implementation of worship, accompanied the leader of the Church.

Based on this explanation, it can be said that women's activities were never completed in a day. Even from dawn until night, women still do activities. Therefore, 
additional activities in the public sector as described above then adjusted in time to ensure women's involvement. Whatever it was, women's activities cannot be separated as part of women's self-actualization in daily activities. Compared to men, women took more time to work than men. Thus, women's activities in general can be explained in two processes, they are:

1. The process of meeting economic needs, which women's activities that contribute to family income,

2. The process of meeting social needs which women's activities that did not contribute to income, but strengthen the social bond between citizens.

This was in accordance with research (Huyer, 2016) that, aspects that need to be considered in job relations between men and women in agriculture, were: (1) Technology needs to be understood in the context of local knowledge, culture, gender relations, capacity, and ecosystem. (2) Technology was not gender neutral, and can strengthen the gender and power relations that cause inequality. (3) The roles and gender relations were changed in response to socio-economic and environmental pressures, changes in work patterns, and technology.

The income was the result of a source of income for each household. The farming income was the multiplication of production obtained with the sale price (Mardani, Nur, \& Halus, 2017). The following table outlines the women activities in the relation to livelihood strategies contributions, in particular providing additional household income as shown in Table 3.

Table 3 Household Income which Obtained by Women

\begin{tabular}{cccc}
\hline No & $\begin{array}{c}\text { Per Month Income Categories } \\
\text { (Average income in October and } \\
\text { November) }\end{array}$ & $\begin{array}{c}\text { Numbers of } \\
\text { informants }\end{array}$ & $\begin{array}{c}\text { Percent } \\
\text { (\%) }\end{array}$ \\
\hline 1 & <p. 2.400 .664 & 8 & 26,7 \\
2 & $\geq$ Rp. 2.400 .664 & 22 & 73,3 \\
& Total & 30 & 100,0 \\
\hline
\end{tabular}

Source : Research Result (processed), 2019

Based on Table 3, it can be seen that, all women contributed to household income. However, especially in the table above adjusted to the Minimum Wage of Regional Province (UMR) of Maluku Province in 2019, amounting to Rp. 2,400,664 (Maluku Governor's Decree Number 433 of 2018). Apparently, there were 26.7 percent of women who had incomes according to the UMR. This means, women provided great benefits in household income. It did not compare with the men income, because in terms of local customs and culture, men were the main breadwinners of households. Therefore, women's income was measured only to see the compatibility with government standards through the Regional Minimum Wage (UMR). It was slightly different from the results of the research (Sopamena \& Pattiselanno, 2018), (Sopamena J. F., 2019c), where income below the UMR was still around 23.7 percent. Even though the results of the research (Salaa, 2015) and (Tuwu, 2018) also showed the importance role of women (housewives) in fulfilling the family economy, it was not only in terms of low or high their contributions to family income.

The work income of women's independently, mainly contributed by the results of farming onion commodities. The price of onions which were usually sold in the form of "konde" (weighs $0.7 \mathrm{~kg}$ at a price of Rp. 10,000 per konde). This price when compared to the price of onion commodities in general was relatively more expensive. 
The results of the research (Widyantara, 2018) showed the average selling price received by the onion farmers in Kintamani Sub-district was Rp. 7,092.52 / kg.

Although there were 26.7 percent of women who had an income under Rp. $2,460,000$, but their onion business income was around Rp. 1,500,000 to Rp. $2,100,000$. Overall, the income of onion farming by women contributed between Rp. $1,500,000-2,500,000$ per month. At least, the income contributed by women can support the fulfillment of household needs. The income contribution from women, besides from onion farming were also supported by the business of goat livestock and selling at the port when the ship is anchored. The new thing new in this research was that there was a clear difference between income that contributed by men and women, especially in onion farming, which was the only source of female income without male intervention. Women were active as onion commodity farmer and food seller when the ship was anchored on Lakor Island. While men focus on raising goats, buffalos and horses. Even if there were men who did onion farming, then women will focus on selling when the ship is anchored. The different thing was in deciding something in the household then all activities were carried out together and are joint decisions between men and women.

The changed of point of view of women contributed to household income differed from studies (Bertrand, Emir, \& Panami, 2015). The results of their research made it clear that social norms cause "a man must get more from his wife", affected the relative distribution of income in the household, the availability of employment opportunities for women, and the allocation of production activities in the house between husband and wife (men and women). The relative advantage in female labor market opportunities over the past half century has made aspects of gender identity more relevant. The changes in income contribution (economic aspects) were very important because they occurred faster than social norms that moved slowly, in supporting gender balance.

\section{CONCLUSION}

The women through onion farming performed the functions of solidarity allocation, integration and expression allocation, political allocation, and allocation of sustainability. The allocation of sustainability was very evident in the efforts of women independently, contributed to household income. Through its contribution, women established themselves as individuals who play an important role in the sustainability of their household's livelihood.

All female informants expressed their idea that, whatever was done was an obligation so it must be done. No work has been refused, so the time allocated by women from waking up to going to bed can be said to be excessive, even far above the time of men. The amount of time allocated by women was a result of the many activities that must be carried out as an obligation. In addition to work at home, women also do various jobs outside the home which were categorized as domestic work. The work as an onion farmer placed women in their whole as the household economic sustainability. In fact, women were able to contribute Rp. 1,500,000 $2,500,000$ per month to the household income. This income was entirely donated by women without the intervention of men.

\section{RECOMMENDATION}

The movement of women to fully contribute in their households required special attention. Attention was emphasized so that women did not forget their 
cultural roots as mothers and also wives who took care of their children and husbands. Therefore, women should pay attention to their position when compared to men. Thus, the efforts to duplicate men's identities can be avoided while at the same time maturing the values of joint work between men (husband) and women (wife).

The household was also expected to pay attention to the decision-making process that was carried out jointly between men and women. The authority in making decision was not determined by the amount of the household income, but by the presence of men and women in carrying out business activities in meeting household needs. Therefore, men (husbands) were expected to pay attention and provided the appropriate place for women (wives) who contributed independently to their household income.

\section{THANK-YOU NOTE}

This research can be held based on the Research Task Letter of the Dean of the Faculty of Agriculture, Pattimura University Ambon.

\section{REFERENCES}

Babbie, E. (2004). The Practice Of Social Research. Belmont: Thomson / Wadsworth.

Badan Pusat Statistik. (2017). Kecamatan Pulau Lakor Dalam Angka Tahun 2017. Tiakur: BPS Kabupaten Maluku Barat Daya.

Badan Pusat Statistik. (2018). Kecamatan Pulau Lakor Dalam Angka Tahun 2018. Tiakur: Badan Pusat Statistik Kabupaten Maluku Barat Daya.

Bertrand, M., Emir, K., \& Panami, J. (2015). Gender Identity And Relative Income Within Households. The Quartely Journal of Economics, 571-614.

Brumer, A. (2008). Gender Relations in Family-Farm Agriculture and Rural-Urban Migration in Brazil. Latin American Perspective, Issue 163, Vol 35 (6), 11-28.

Debus, M., \& Novelli, P. (1996). Methodological Review: A Handbook for Excellence in Focus Group Research. Washington: Academy for Educational Development.

Huyer, S. (2016). Closing the Gender Gap in Agriculture. Gender, Technology and Development Vol 20 (2), 105-116.

Mardani, Nur, T. M., \& Halus, S. (2017). Analisis Usahatani Tanaman Pangan Jagung di Kecamatan Juli Kabupaten Bireuen. Sains Pertanian, 203-212.

Norman, D. K., \& Yvona, L. S. (1994). Handbook of Qualitative Research. Newbury Park, CA: Sage Publications.

Sahusilawane, A. M. (2019). Perempuan dan Usaha Ternak Domba di Desa Purpura Kecamatan Kisar Utara. Agrilan Vol 7 (3), 265-277.

Salaa, J. (2015). Peran Ganda Ibu Rumahtangga dalam Meningkatkan Ekonomi Keluarga di Desa Tarohan Kecamatan Beo Kabupaten Kepulauan Talaud. Holistik Tahun VIII (15), 1-16. 
Sopamena, J. F. (2018). Konstruksi Gender, Strategi Nafkah, dan Kearifan Lokal ,Studi Kasus Tnyafar di Pulau Selaru Kabupaten Maluku Tenggara Barat. Disertasi. Malang, Jawa Timur, Indonesia: Universitas Brawijaya Malang.

Sopamena, J. F. (2019a). Peran Gender Dalam Rumahtangga Masyarakat Pulau Kecil Studi Kasus Kecamatan Teluk Ambon Baguala Kota Ambon. Jurnal Agribisnis Terpadu Edisi 12 (1), 72-86.

Sopamena, J. F. (2019b). Resiliensi Nafkah Rumahtangga Masyarakat Pulau Kecil, Studi Kasus Pulau Wetar Kabupaten Maluku Barat Daya. Habitat Vol 11 (2), 79-87.

Sopamena, J. F. (2019c). Kontribusi Perempuan Terhadap Penerimaan Rumahtangga Masyarakat Pulau Kecil Studi Kasus Kecamatan Teluk Ambon Kota Ambon. JEPA Vol 3 (4), 720-729.

Sopamena, J. F., \& Pattiselanno, A. E. (2018). Tnyafar : Women, Livelihood Strategy in Selaru Island, West Southeast Maluku District. IJEAB Vol 3 (5), 1685-1690.

Srinivas, T., Malika, A.-M., Aden, A.-H., Barbara, R., Markos, T., \& Javed, R. (2013). Gender Roles in Agricultre : The Case of Afghanistan. Indian Journal of Gender Studies Vol 20 (1), 111-134.

Sukesi, K. (2009). Bias Gender dalam Pekejaan Domestik Rumah Tangga Domestik dan Buruh Mkigran. Analisis Sosial Vol 14 (1), 105-124.

Tuwu, D. (2018). Peran Pekerja Perempuan dalam Memenuhi Ekonomi Keluarga : Dari Peran Domestik Menuju Sektor Publik. Al Izzah : Jurnal Hasil-Hasil Penelitian Vol 13 (1), 63-76.

Widyantara, W. (2018). Strategi Petani Bawang Merah dalam Usaha Memperoleh Laba Pada Agribisnis Bawang Merah di Lokasi Spesifik, Desa Buahan Kecamatan Kintamani Kabupaten Bangli. SOCA Vol 12 (2), 144-151. 